\title{
Article \\ Just a Shadow? The Role of Radical Right Parties in the Politicization of Immigration, 1995-2009
}

\author{
Sarah Meyer * and Sieglinde Rosenberger \\ Department of Political Science, University of Vienna, 1010 Vienna, Austria; E-Mails: sarah.meyer@univie.ac.at (S.M.), \\ sieglinde.rosenberger@univie.ac.at (S.R.) \\ * Corresponding author
}

Submitted: 13 May 2014 | In Revised Form: 11 November 2014 | Accepted: 8 January 2015 |

Published: 28 April 2015

\begin{abstract}
The paper explores the role of radical right parties in the politicization of immigration. In scholarly literature, radical right parties are viewed as the owners of the immigration issue and as drivers of its politicization. Against this prevalent view, we argue that the significance of radical right parties in politicizing immigration is overrated: (1) Radical right parties only play a subordinate role in the politicization of immigration, whereas the contribution of mainstream parties to raising issue salience has been underestimated; (2) the politicization of immigration is not related to radical right strength in the party system. The findings are based on media data from a comparative project on public claims-making on immigration in Western European countries (SOM, Support and Opposition to Migration). We discuss our findings in comparison to the relevant literature and suggest avenues for further research.
\end{abstract}

\section{Keywords}

claims-making; immigration; issue politicization; radical right parties

\section{Issue}

This article is part of a regular issue of Politics and Governance, edited by Professor Andrej J. Zwitter (University of Groningen, The Netherlands) and Professor Amelia Hadfield (Canterbury Christ Church University, UK).

(C) 2015 by the authors; licensee Cogitatio (Lisbon, Portugal). This article is licensed under a Creative Commons Attribution 4.0 International License (CC BY).

\section{Introduction}

Populist, radical, and extreme right-wing parties have established themselves as serious political competitors in Western European politics in the last few decades. Some of them experienced electoral triumphs, such as the Lijst Pim Fortuyn (LPF) in the 2002 elections in the Netherlands, the Swiss People's Party (SVP), which became the strongest party in 1999, or the Austrian Freedom Party (FPÖ) winning 27 per cent in the 1999 elections and becoming part of a coalition government as a result, which was widely interpreted as the crossing of a border-line (cf., Minkenberg, 2001). Meanwhile, various parties from the populist or radical right camp, like the LPF (2002) and Geert Wilders' Party for Freedom (PVV) (2010) in the Netherlands, also succeeded in of- fice-seeking. Despite different terminology-like populist, new populist, radical or extreme right-wing parties-all of these parties share an anti-immigrant stance embedded in a nationalist or even xenophobic ideology that has often been accompanied by a strong anti-Islamic rhetoric in recent years. In line with Minkenberg (2008), Norris (2005), Kitschelt (1995) and others, we will refer to them as radical right parties in the following. ${ }^{1}$

Academic work suggests that the success of these parties has had a lasting impact on the political landscape in Western Europe. First, some scholars find evi-

\footnotetext{
${ }^{1}$ This, however, does not imply that there are not any differences between these labels (cf., Carter, 2005, pp. 20-24 for a good overview of scholarly dispute on this).
} 
dence of an impact the electoral success of the radical right has on people's attitudes towards immigration (cf., Semyonov, Raijman, \& Gorodzeisky, 2006; Sprague-Jones, 2011). Second, the experience of electoral pressure of the radical right prompts other parties to adapt their policy programs and mobilization strategies: the center-right by adopting a strategy of convergence, whereas the center-left uses convergence and divergence strategies (Meguid, 2005) (cf., van Spanje, 2010; Alonso \& Fonseca, 2012). Third, there is substantial evidence for a tightening of immigration policies (cf., Givens \& Luedtke, 2005). Some scholars view this as a consequence of the radical right parties' participation in governing coalitions or as mainstream governing parties' response to the former's electoral success (cf., Minkenberg, 2001; Schain, 2006). These observations, finally, cause both academics and political commentators to claim an overall swing to the right (Rechtsruck, Verrechtsing) in European democracies (cf., Westin, 2003).

Though labelling them single-issue parties would be an inadequate evaluation of the radical-right party family (cf., Mudde, 1999), the immigration issue certainly features prominently in their profile and campaigning. As a consequence, radical right parties are viewed as the "owners" of the immigration issue in the party political landscape (cf., Ivarsflaten, 2008; Mudde, 1999; van Spanje \& van der Brug, 2007). The success of the radical right thus seems paralleled by the rise of topics related to immigration, migrant integration and asylum that have become contentious issues all over Europe.

Following a top-down perspective of issuepoliticization, political actors are considered determined to put an issue on the political agenda, framing the public debate, and influencing people's preferences and priorities (cf., Carmines \& Stimson, 1986, 1989; Hooghe \& Marks, 2009). There is hardly any empirical evidence on party-politicization of the immigration issue in the public arena: Whilst numerous studies deal with party platforms and campaigning efforts (cf., Gruber, 2014; van Heerden, de Lange, van der Brug, \& Fennema, 2014), the extent to which immigration becomes part of political contestation in every-day mass communication has been widely neglected. Nonetheless, taking the above cited literature on influence and issue-ownership into account, radical right parties are supposed to play a key role in the politicization of immigration in public discourse (cf., Hagelund, 2003; Meguid, 2005; Minkenberg, 2002; Norris, 2005; Schain, 2006; van Spanje, 2010).

The paper at hand puts this prevalent view to the test, addressing a straightforward and simple research question: Do radical right parties dominate the politicization of immigration in public discourse? The study is based on findings from the FP7 project SOM (Support and Opposition to Migration) ${ }^{2}$ that compared claimsmaking on immigration in the media of several Western European countries between 1995 and 2009. Our research includes cases with a strong radical right party presence during the whole period (Austria, Switzerland), with radical right parties that have been successful at least for some periods (Belgium, the Netherlands), and countries with no such parties represented in national parliament (Spain, the United Kingdom). As the objective of this paper is not to test explanations for the politicization of immigration, but to explore the role of radical right parties, we mainly present detailed descriptive findings and discuss them within the context of the alleged significance of radical right parties claimed in scholarly literature.

Based on our data, we put forward two arguments: (1) Radical right parties only play a subordinate role in the politicization of immigration in the mass media, whereas the contribution of mainstream parties to raising issue salience has been underestimated; $(2)$ issuepoliticization on immigration is not related to radical right strength in the party system. While our findings contradict the alleged significance of populist, radical and extreme right parties discussed in the relevant literature, they support recent contributions by scholars discomforted by the lack of systematic comparative analyses and claiming that the impact of these parties on contemporary politics is clearly overestimated (cf., Akkerman, 2012; Alonso \& Fonseca, 2012; Mudde, 2013).

\section{Radical Right Parties and the Politicization of Immigration}

Processes of issue-politicization have traditionally been at the centre of interest in political science (Carmines \& Stimson, 1989, 1986; Schattschneider, 1975). Broadly speaking, issue-politicization refers to the process whereby a topic becomes relevant for public debate and political contestation. De Wilde (2011, pp. 566567) names three stages of that process: a polarization of opinions (i.e., some sort of conflict), intensified public debate, and public resonance. When issues are deemed politically relevant by the general public and hence become politicized, this might also result in an increase of their electoral importance. Consequently, while processes of issue-politicization can involve different societal actors, political parties and their strategies are key actors in this respect (cf., de Wilde, 2011; Green-Pedersen, 2012).

According to Green-Pedersen (2012, p. 117), politicization is equivalent to saliency, and whether a party

\footnotetext{
2 This work was supported by the European Commission's Seventh Framework Programme for Research (FP7/20072013) under grant agreement number 225522 (SOM: Support and Opposition to Migration).
} 
will politicize a certain issue (i.e., raise its salience) is dependent on strategic considerations related to party competition dynamics. The salience theory of party competition states that parties compete by strategically manipulating the saliency of issues, i.e., by emphasizing issues that they expect to be beneficial in electoral terms while downplaying those likely to cause electoral damage (cf., Budge, 1982; Budge \& Farlie, 1983; Budge, Klingemann, Volkens, Bara, \& Tannenbaum, 2001). The salience theory suggests that parties "own" different issues (cf., Budge, 1982), i.e., certain parties are associated with certain issues because their previous activities or their constant focus on these issues (e.g., through their parliamentary work, government policy, or campaigning) have earned them a reputation and credibility. Competing for voters, parties will therefore try to emphasize "their own" issues. However, even without owning an issue, political parties can emphasize specific issues in reaction to changes in the political environment or because they cannot ignore issues strongly emphasized by their competitors. Beyond issue-ownership, a number of other factors determine whether politicizing an issue is likely to be beneficial or disadvantageous for a party-in particular, whether the issue fits a party's ideological profile and whether there is congruence between party and voter positions with regard to the issue (cf., Hooghe \& Marks, 2009; Steenbergen \& Scott, 2004).

Over the last few decades, questions related to immigration, immigrant integration, and asylum have been contested issues in public discourse and subject to party conflict. In scholarly literature, public contestation over the issue of immigration is often discussed with regard to the success of one specific actor, namely the radical right party family. These parties strongly mobilize against immigration and are widely viewed as the "owners" of the issue (cf., Ivarsflaten, 2008; Mudde, 1999; van Spanje \& van der Brug, 2007). While there is disagreement as to the precise definitions of "radical right", "extreme right", and "(new) populist right", 3 they all share an anti-immigrant rhetoric, sometimes combined with ethno-nationalism and, more recently, anti-Islamic polemic. The respective parties "seek to mobilize support around some form of national/regional identity, accompanied by anti-ethnic minority sentiments" (Eatwell, 2000, p. 349), turning above all against (mostly non-white) immigrants, which are often stigmatized as a social burden and cultural threat.

The immigration issue perfectly fits the profile of radical right parties, who strive for a homogenous national identity based on an ethno-centric understanding of community, which they share with their voters. It

\footnotetext{
${ }^{3}$ For a useful summary see Carter (2005, pp. 14-23; cf. also, Eatwell, 2000; Kitschelt, 1995; Minkenberg, 2000; Mudde, 1996; Rydgren, 2007, 2005; Taggart, 1995).
}

also provides them with strategic assets on the electoral market, challenging both left and right mainstream competitors (cf., Alonso \& Fonseca, 2012; Bale, Green-Pedersen, Krouwel, Luther, \& Sitter, 2010), whose more moderate positioning is challenged from both sides of the political spectrum - the radical right anti-immigrants and pro-immigrant libertarian parties. Therefore, according to the salience theory of party competition, radical right parties supposedly are key players in the politicization of immigration: they can be expected to put more emphasis on the immigration issue in public discourse than any other party family.

Beyond emphasizing the issue themselves, radical right parties may also have an indirect impact on the politicization of immigration. Such indirect effects are related to party competition dynamics. First, the extreme positioning of the radical right may provoke counter-mobilization by pro-immigrant parties, whose party profile is based on libertarian values like tolerance, human rights and multiculturalism. Such countermobilization may even extend to non-party actors from civil society or the media, who oppose a nationalist concept of an ethnically, culturally and religiously homogenous society. Second, radical right issueownership could force mainstream party competitors to engage in competition over the issue themselves: Challenged by electoral threats from the radical right, mainstream left and right parties - who initially competed on the economic rather than the cultural dimension of conflict (cf., Lipset \& Rokkan, 1967) and whose electorate is divided on questions of immigration - will no longer be able to suppress the issue. The pressure on mainstream parties to get involved in the debate on immigration will be dependent on the strength of their radical right competitors: claims made by hardly successful radical right parties with a small electorate located at the fringes of the political spectrum can more easily be ignored compared to the stronger and growing ones, who alienate voters from mainstream parties.

In both examples, the presence of radical right parties in the party system will boost the salience of the immigration issue in public discourse, presumably even beyond party actors.

Though there is a growing number of studies dealing with party representation in media coverage on issues related to immigration (e.g., Helbling, 2014; Koopmans, Statham, Giugni, \& Passy, 2005; Statham \& Geddes, 2006), systematic data on the politicization of immigration and the role of parties therein are still missing.

Following the literature on party competition and considering the potential direct and indirect impacts of radical right parties on the politicization of immigration in public discourse, we arrive at the following hypotheses: (1) radical right parties are the decisive actors in the politicization of immigration showing the largest share of claims in the media; (2) countries with rele- 
vant radical right parties will reveal stronger politicization (i.e. issue salience) in public discourse compared to countries lacking such presence; (3) the stronger radical right parties (in terms of electoral success), the more politicized the immigration issue.

So far, we discussed the politicization of immigration in connection with party politics dynamics, and radical right party agency in particular. However, the literature also offers alternative explanations, which shall be discussed briefly. Scholars have long argued that the salience of an issue in public discourse would be related to "objective" conditions regarding the societal phenomenon at stake-in this case: immigration. Objective conditions, in this regard, refer to actual challenges or threats that immigration presents to society and people's lives. The number of immigrants would then be an indication of the potential conflict that receiving societies are confronted with: the higher the share of immigrants of the total population, the greater the (potential) challenge; and the greater the challenge, the more issue-politicization. However, there is still hardly any empirical evidence for this hypothesis, in particular for explaining variations in issuepoliticization over time (cf., Vliegenthart \& Boomgaarden, 2007; van der Brug, D’Amato, Berkhout \& Ruedin, 2015). This illustrates that the immigration issue-and most likely other issues as well-do not simply appear on the public agenda as a matter of course in response to "objective" challenges or problems. Rather, issues have to be taken up and emphasized by societal and political elites who will be heard in public discourse.

Another potential explanation for the rise and decline of immigration as an issue of public controversy points to the role of events (cf., Vliegenthart \& Boomgaarden, 2007). In the Netherlands, for instance, the murder of filmmaker Theo van Gogh by a Muslim fundamentalist and second-generation immigrant in 2004 led to a huge debate on multiculturalism and immigrant integration. In 2007, asylum policy became a priority topic on the public agenda in Austria after a 17year-old girl went into hiding and threatened to commit suicide after her family had been deported to Kosovo. Protest activities in Switzerland against the building of minarets led to an intensified debate on Muslim immigrants in 2006. Unlike objective facts such as immigration statistics, peaks in the politicization of immigration in certain cases can be traced back to specific events that-for various reasons-drew public attention (Vliegenthart \& Boomgaarden, 2007).

Approaching issue-politicization, like defined above, as a process of publicly expressed political contention, the role of yet another important actor needs to be discussed: the media. As both forum and actor, mass media have a twofold function in shaping public discourse. As a forum, they distribute news and stories reported to the general public; as an actor, the media themselves shape such news and stories, first, by deciding what issues and whose claims they include in their coverage, and, second, by acting as claimants themselves (cf., Page, 1996). Like other arenas of political contention, the media arena has its own functional logic defining the boundaries of public debate over an issue. We will return to this point in more detail in the section on data and methods.

\section{The Varying Strength of Radical Right Parties in Europe}

The political strength of radical right parties varies considerably in Western European countries. Whilst there are no simple answers as to why these differences have emerged, scholars highlight the importance of supply-side factors in explaining radical right electoral success (cf., Carter, 2005; Givens, 2005; Norris, 2005; van der Brug, Fennema, \& Tillie, 2005). ${ }^{4}$

In Austria, Belgium, the Netherlands, and Switzerland, radical right parties representing an overtly nationalist and anti-immigrant approach (cf., Rydgren, 2005) have gained considerable electoral votesthough with varying success in the various countries and over time-and are thus to be considered relevant for party political contestation (cf., Sartori, 1976). In contrast, in Spain and the UK no proponent of the radical right party family has so far passed the electoral threshold to be represented in national parliament.

The radical right Austrian Freedom Party (FPÖ) had its first electoral triumph in the late 1980s, reaching the peak in 1999 when it became the second strongest party with 26.9 per cent, forming a coalition government with the Christian-democrats (ÖVP). Despite an intra-party dispute, the collapse of the coalition government, and a sharp decline in the early elections of 2002 , the radical right continued to play a significant role in the Austrian party system (Heinisch, 2003). With the FPÖ split-off in 2005, another radical right party actor was represented in parliament, the BZÖ. The BZÖ, founded by former FPÖ-figurehead Jörg Haider, gained 4.1 per cent in the 2006 elections and increased its share of the vote to 10.7 per cent in 2008 . Together with the FPÖ regaining strength, the radical right bloc reached 28.1 per cent and 55 out of 183 seats in parliament, thus surpassing the FPÖ's 1999 victory. $^{5}$ Whilst it is true that the FPÖ's (and BZÖ's) electoral success cannot only be attributed to the immigration

\footnotetext{
${ }^{4}$ For a state-of-the-art summary see van der Brug \& Fennema (2007).

${ }^{5}$ The 2013 election brought significant changes to the Austrian party political landscape: while the BZÖ failed to reach the 4 per cent threshold to be represented in parliament, two new parties succeeded, and for the first time six parties are represented in parliament. Despite new competitors, the FPÖ further increased its share of the vote to 20.5 per cent.
} 
issue, the latter definitely played-and still plays-a significant role (cf., SORA, 2006). FPÖ electoral campaigning is characterized by reference to the concept of Überfremdung ("foreign domination"), the guiding principle Österreich zuerst! ("Austria first!"), and (more recently) anti-Islamic rhetoric (cf., Gruber, 2014; Krzyzanowski, 2013; Rosenberger \& Hadj-Abdou, 2013; Wodak \& Köhler, 2010).

In Belgium, the success of the radical right parties varies greatly in the two regions: whereas the Flemish Vlaams Belang (VB, former: Vlaams Blok ${ }^{6}$ ) managed to increase its share of the vote gradually from 7.8 to 12 per cent in 2007, the Front National in French-speaking Wallonia failed to reach a comparable percentage and significance. The unique significance of regional differences in Belgium defines the political landscape. However, the Vlaams Belang replaced the striving for independence-traditionally the primary objective of Flemish nationalist parties-by putting greater emphasis on the immigration issue (Minkenberg, 2008). Similar to the concept of Überfremdung, the Vlaams Belang's credo Eigen volk eerst ("our people first") reflects a clear separation between a constructed national (or regional) unity and an outside threat, namely immigrants. Until today-and in contrast to Austria, the Netherlands, and Switzerland-the party is widely isolated within the Belgian political system as a consequence of the cordon sanitaire struck by all other parties (cf., Downs, 2001).

In the Netherlands, the anti-immigrant Lijst Pim Fortuyn gained 17 per cent of the votes and 26 seats in parliament in the 2002 elections. ${ }^{7}$ Despite this shortlived success, it is considered to have substantially affected politics in the Netherlands, which was previously characterized by widespread acceptance of the multiculturalist approach upholding the inclusion and tolerance of ethnic, cultural, and religious minorities (Minkenberg, 2008). While neither the LPF nor respective party splits could measure up to the 2002 results, the 2006 election brought forth another antiimmigrant radical right party, namely Geert Wilders' PVV, which managed to win 5.9 per cent, increasing its share of the vote to 15.5 per cent in 2010. The PVV mainly focusses on anti-Muslim campaigning, justified by the explicit support of libertarian attitudes like gay rights and emancipation of women. ${ }^{8}$

6 The party was reestablished under its new name after a court decision in 2004 had found the Vlaams Blok guilty of racism.

7 In the late 1980s and early 1990s, the nationalist, antiimmigrant Centre Democrats (CD) were temporarily successful when entering national parliament. Failing to repeat this success in the 1999 general election, the party then disappeared from the political lanscape.

8 Between 2010 and 2012 (a period which is not covered by our data), the major success of Wilders' party allowed the
In terms of continuous electoral success, parliamentary presence, and government participation, the Swiss People's Party (SVP) is the most prosperous rightwing anti-immigrant party included in our analysis. Though not a radical right party in terms of its historical origins, we treat the SVP as part of the radical right family because of its pronounced ethno-nationalist stance and populism, indicated not least by the party's recurring reference to the concept of Überfremdung (Skenderovic \& D’Amato, 2008; Minkenberg, 2008). ${ }^{9}$ Due to the SVP's electoral achievements and Switzerland's consociational government that includes all major parties, Switzerland ranks first among the countries observed in terms of radical right strength between 1995 and 2009: during that period, the SVP kept increasing its share of the vote from 14.9 to 28.9 per cent in 2007, and it has been Switzerland's strongest party since the 1999 election.

In contrast to the aforementioned countries, radical right parties are not represented in the national parliaments of the United Kingdom and Spain. In the UK, the first-past-the-post electoral system clearly privileges mainstream parties, although radical right, antiimmigrant parties, i.e. the British National Party (BNP) and the United Kingdom Independence Party (UKIP), have been successful at the local and European level in recent years. ${ }^{10}$ Besides withdrawal from the European Union, the immigration issue is the most important item on the political agenda of these parties, focusing, in particular, on economic arguments associated with nationalist views (Halikiopoulou \& Vasilopoulou, 2010).

Likewise in Spain, anti-immigrant radical right parties have only been successful at the local level, and only in recent times (cf., Ros \& Morales, 2012). One reason for their poor performance, scholars argue, is their failure to dissociate themselves from associations with ideologies of the Franco regime (Norris, 2005). Another aspect stressed in the literature is the mainstream right Popular Party's (PP) success in attracting far-right voters (cf., Ros \& Morales, 2012).

Having briefly described the radical right parties in the six countries included in our research, we sum up the common features and differences of the parties and countries respectively: four countries have strong radical right parties, with varying electoral success. Switzerland and Austria rank first with an average of 23

formation of a minority government under the conservative Christen Democratisch Appèl leadership and the connivance of the PVV (Wilp, 2012).

${ }^{9}$ The SVP is said to be close to conservative and radical right parties due to its strong roots in national conservatism and its vigorous populist anti-immigrant stance since the early 1990s (Statham \& Koopmans, 2009, p. 443).

10 The British National Front was successful at local elections only during the 1970s and has since then practically lost its political significance. 
per cent and 20 per cent of the seats respectively between 1995 and 2009, followed by Belgium (12 per cent) and the Netherlands (4 per cent) (see Table 1). While some radical right parties have gradually increased their power (SVP, VB), others like the FPÖ, $B Z O ̈, L P F$ and PVV have failed to continue their development, which is mainly due to internal crises. Three of these parties joined national governments as coalition partners, namely the Swiss SVP, the Austrian FPÖ/BZÖ and the Dutch LPF. ${ }^{11}$ Whilst not all of the parties mentioned in this section fit the radical right label, all of them, including the less important British and Spanish parties, share a pronounced anti-immigrant ideology and can thus be expected to play a significant role in the politicization of immigration.

Table 1. Radical right party strength at the national level (1995-2009).

\begin{tabular}{llll}
\hline Country & RR & $\begin{array}{l}\text { RR share of } \\
\text { parties }\end{array}$ & RR gov-part \\
& FPÖ, & $23-22-28-$ & $2000-2003$ \\
Austria & BZÖ & $15-30$ & $2003-2007$ \\
Belgium & FN, VB & $9-11-13-12$ & -- \\
Netherlands & LPF, & $2-0-17-5-6-$ & $2002-2003$ \\
& PVV & 15 & \\
Spain & -- & -- & - \\
Switzerland & SVP & $15-22-28-$ & $1995-$ \\
& & 31 & $2009^{*}$ \\
United & BNP, & -- & -- \\
Kingdom & UKIP & & \\
\hline
\end{tabular}

Notes: RR parties: radical right parties present in country; RR share of seats: radical right parties' share of seats in national parliament in the period 1995-2009 for each legislative period (number of elections varies from country to country); RR gov-part: radical right party representation in national government. *Consociational government including all major Swiss parties.

\section{Data and Methods}

This paper approaches the matter of issuepoliticization of immigration in the public sphere with a particular focus on party actors, especially radical right parties. The analysis is confined to six Western European countries between 1995 and 2009: Austria, Belgium, the Netherlands, Spain, Switzerland, and the United Kingdom. The time frame and country selection are based on requirements for over-time and cross-country variation regarding (expected) issue salience, radical right party strength, and immigration patterns (cf., van der Brug et al., 2015). Data were collected as part of the FP7 project SOM (Support and Opposition to Mi-

11 Though Geert Wilders' PVV supported a minority government of the liberal-conservative VVD and the Christiandemocratic CDA between 2010 and 2012, the PVV was not part of the cabinet. gration), a comparative project investigating the role of different actor types in the politicization of immigration by means of a claims-analysis of media data. As argued by de Wilde (2011, p. 562), "whether an issue is politicized or not and deemed important by the electorate can indirectly be assessed by studying the extent to which it is publicly debated". Media data are increasingly used to studying public contestation and mobilization over issues (e.g., Koopmans et al., 2005; Koopmans, 2007). They reflect the publicly visible expression of claims on an issue raised by a broad range of societal actors. This is quite important, as a focus on politicization differs from studying party conflict. The latter refers to different positions parties may hold on an issue-whether or not they find expression in public discourse or remain latent. Issue-politicization also considers the possibility that non-party actorsincluding the media themselves - play a crucial role in raising the saliency of an issue, for which these actors have to be included in the analysis. Neither party manifestos nor data from parliamentary activity meet these requirements.

However, using media data also implies certain limitations resulting from the media's function as gatekeeper to public discourse: It is journalists and editors deciding what stories and which actors to include in media coverage, and what framing to apply to a certain event or issue. Therefore, media coverage may not represent a balanced picture of different actors' efforts to engage in the politicization of an issue. In particular, there is strong evidence in communication studies "that government officials serve as the chief sources of many kinds of political news" (Page, 1996, p. 22). Consequently, governing actors seem to dominate claimsmaking on politically relevant issues in the media (e.g., Koopmans et al., 2005; Koopmans, 2007), since their claims are viewed either as more newsworthy or reliable, or because government actors have better access to journalists and editors. Analysing various actors' engagement in the politicization of an issue, we thus have to keep in mind that some actors-and governing actors in particular-may have privileged access to the media because of their political or economic power or their prominence.

Conversely, other actors may suffer from more explicit exclusionary dynamics resulting from broad political and public consensus challenging the legitimacy of these actors' claims. Recall the cordon sanitaire in Belgium, which could result in an underrepresentation of the radical right's claims in the news, if media actors comply with this elite consensus. On the other hand, radical right parties' extreme positioning yields great potential for political conflict, raising the newsworthiness of these actors' claims. This also applies to cases with charismatic party leaders, as for instance the Austrian Freedom Party's Jörg Haider or the Swiss People's Party Christoph Blocher in the 1990s, whose unambig- 
uous populism made for better stories than sophisticated policy programs presented by some political competitors. Finally, the more established radical right parties become in the party system (indicated e.g., by their share of seats in parliament or participation in government), the less likely they will be considered negligible actors by the media. In conclusion, there is no reason why one should expect the media in general not to cover claims of the radical right. If anything, radical right parties must make their claims and actions visible in public in order to achieve the status as "owners" of the immigration issue.

Applying claims-analysis, a total of 6586 claims were coded from newspaper articles for the six countries, taking two to four papers from each country. ${ }^{12}$ Political claims-analysis is a method developed by social movement scholars which is increasingly used for examining mobilization strategies of politically relevant actors (cf., Koopmans et al., 2005; Koopmans \& Statham, 2000). An instance of claims-making (henceforth: a claim) is defined as a unit of strategic physical or verbal action in the public sphere that entails a "purposive and public articulation of political demands, calls to action, proposals, criticisms, or physical attacks, which actually or potentially, affect the interests or integrity of the claimants and/or other collective actors" (Koopmans et al., 2005, p. 24, emphasis in the original). Political claims comprise various elements, including a claimant, a topic or political demand, an addressee as well as a potentially affected object actor (Berkhout \& Sudulich, 2011) ${ }^{13}$. In this paper we focus on the claimant (i.e., the actor making the claim) and-in case of party actors-party affiliation ${ }^{14}$. In total, we distin-

12 The selected newspapers are: Der Standard, Neue Kronen Zeitung (AT); De Standaard/Le Soir, Het Laatste Nieuws/La Dernière Heure (BE); The Irish Times, Irish Daily Star (EI); Volkskrant, Telegraaf (NL); El País, La Vanguardia (ES); Neue Zürcher Zeitung/Le Temps/Tribune de Genève, Blick/Le Matin $(\mathrm{CH})$; The Guardian, Daily Mail (UK). In Belgium and Switzerland two additional newspapers were included to account for differences between the Dutch and French and the German and French language regions respectively. In Switzerland, the Tribune de Genève is treated as the predecessor of Le Temps; as regards the Spanish paper La Vanguardia the term tabloid does not have the same meaning as in the other countries. For more details on newspaper selections see van der Brug et al. (2015).

13 The SOM Codebook comprises additional categories, inspired by Codebooks of similar projects, including $\mathrm{MERCl}$ (Koopmans et al., 2005), EUROPUB (Koopmans, 2002) and LOCALMULTIDEM (Cinalli \& Giuigni, 2007). The coding of articles was conducted centrally at the Universiteit van Amsterdam under the direction of Wouter van der Brug.

14 Party affiliation was coded for established actors, i.e., gov- guished between six different categories of party families which claims-making party actors have been assigned to (cf., Statham \& Koopmans, 2009, p. 443): the radical right, liberals, conservatives (including Christian-democrats), social democrats, the greens, and finally the radical left. ${ }^{15}$ We approach issue-politicization as a matter of salience or issue emphasis, which we measure as follows: (1) We measure individual parties' engagement in the politicization of immigration as the relative proportion of claims raised by a particular actor on all claims or all claims of a particular actor type (namely: political parties). (2) Salience at the country level will be measured as the number of claims relative to the size of the sample, which varies both between countries and years (see below).

Apart from issue salience, we will also look at the direction of claims, which provides an indication for actors' positioning in the politicization of immigration. The SOM Codebook includes a position variable with five values, distinguishing claims that are (1) strongly or (2) slightly open to migrants or cosmopolitan or multicultural in their focus, or conversely (3) strongly or (4) slightly restrictive to migrants, pro-national residents or mono-cultural in their focus, and (5) neutral claims with a technocratic or ambivalent orientation that has no clear-cut direction. ${ }^{16}$

Figure 1 presents an overview of the total number of claims coded per newspaper and country. For each newspaper, articles relating to issues of immigration, migrant integration and asylum were manually selected by country teams for a random sample of 375 days between 1995 and 2009. ${ }^{17} 18$ Unsurprisingly, we find an uneven distribution of claims reported by different media outlets, with lower numbers in tabloids compared to the quality press, the coverage of which is more claims-focussed as might be expected.

ernment actors, national parliament and legislative assemblies at the regional level as well as representatives of political parties. This allows for an analysis of the overall presence as well as the positions of the respective parties.

${ }^{15}$ All other parties are coded in a seventh category ("others").

${ }^{16}$ Further details can be found in the Codebook (Berkhout \& Sudulich, 2011).

17 The period lasted exactly from January 1, 1995 to December 31, 2009, excluding Sundays.

18 There is an overlap of 50 days between both newspaper samples, while there are differences on 325 days. The exact amount of sampled days for each country are: AT 750, BE 1216, CH 859, ES 753, NL 757, and UK 751. The larger samples in $\mathrm{BE}$ and $\mathrm{CH}$ are due to the selection of additional newspapers to cover different language regions. 


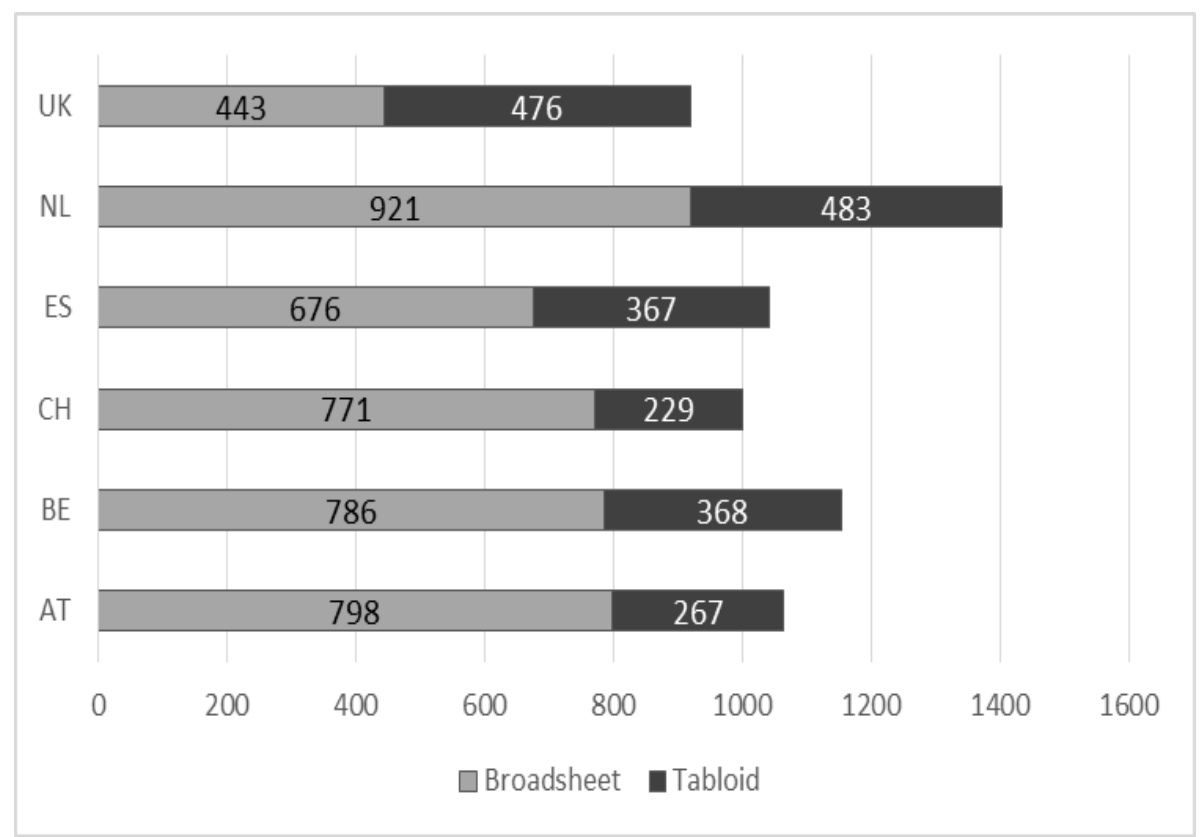

Figure 1. Number of claims on immigration per country (1995-2009).

\section{Findings: Low Salience but Extreme Positioning}

This section presents our empirical findings regarding the role of radical right parties in the politicization of immigration in the public arena. We will first look at claims-making on immigration by individual actors - in particular the radical right party family-before turning to (temporal) patterns in the overall salience of immigration in a given country.

Following the literature, we hypothesized that radical right parties are key players in the politicization of immigration, which should be reflected in a comparatively large share of claims. As illustrated by Figure 2, the share of claims raised by radical right parties is quite small in all six countries. In total only 4.4 per cent of all claims originate from this particular actor group.

Though these figures are indeed low, we need to compare them with the number of claims of other actors in order to come to a meaningful interpretation. It could well be that other non-party actors like civil society organizations or the media dominate the politicization of immigration. In this case the share of radical right party claims - though small in absolute termswould be much higher when compared to other parties. Therefore we check next whether the debate is driven by party actors at all. Table 2 shows the top three actors in our six countries. As we can see, government and party actors are indeed crucial. Except for the UK (where the media is most important) and Belgium (where civil society ranks comparatively high), government and party actors are the two most important actor types. It is important to note that the category of governmental actors may as well include party actors, as in the case of ministers or the like, who do not only speak as representatives of government, but also as prominent members of their parties.

Next we take a closer look at claims-making by party actors, for which we compare party families, as shown in Figure 3. Surprisingly, radical right parties are not the main claimants when compared only to other party actors. In this regard, the Swiss case represents an exception, with the highest share of claims raised by the SVP (38.8 per cent). In all the other countries, we observe that radical right parties play a subordinate role. This does not come as a surprise in the cases of Spain and the UK, where these parties were hardly successful at the ballot box and failed to be represented in parliament. In Austria, Belgium, and the Netherlands, however, one might have expected a larger share of radical right party claims. As a matter of fact, mainstream parties from both the left and the right (i.e. social democrats, liberals, and conservatives) outperform radical right parties in claims-making on immigration.

These findings clearly reject our first hypothesis according to which radical right parties should have a direct impact as key players in the politicization of immigration. In contrast to party family, they suggest that the role political parties play in the politicization of immigration might be a question of party size or government participation. This would also explain the Swiss SVP's comparatively high share of claims, since the party became the strongest party in the Swiss party system in 1999 and is part of the Swiss consociational government.

So far our findings suggest that radical right parties play a subordinate role in the politicization of immigration given their limited contribution to the saliency of the issue in the media. Turning our attention to the direction of claims in issue-politicization, the picture might be a different one. Focusing on the mean positioning on a scale from -1 (negative towards immigra- 
tion/migrant integration/asylum-seekers) to 1 (positive), our findings generally reveal that the debate is slightly biased towards a more liberal orientation (see Table 3). Interestingly, the exception is the United Kingdom, where radical right parties are neither represented in parliament nor do they contribute significantly to the politicization of immigration through claims in the media. Turning to party actors (i.e., excluding claims from all other actor types like civil society, the media etc.), the debate turns more negative in all countries. However, the radical right parties make the most negative claims on immigration. Therefore, they stand out with their negative positions despite their subordinate role regarding issue salience, and thus clearly contribute to the polarization of the debate on immigration.

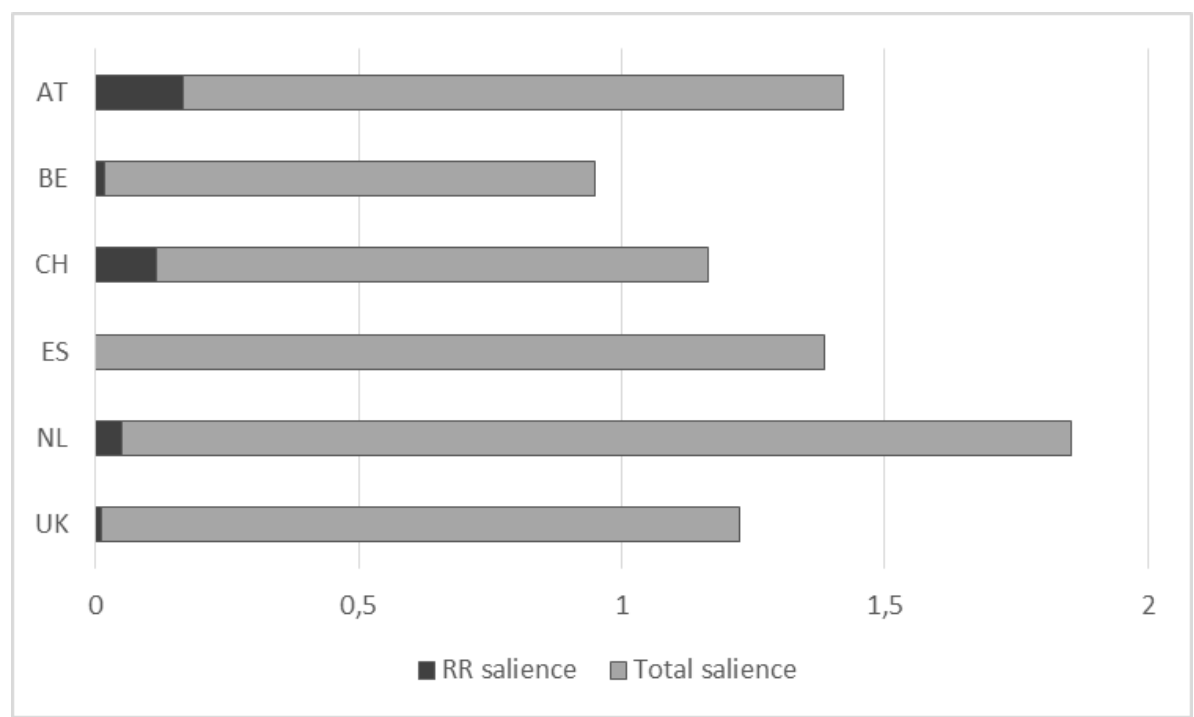

Figure 2. Issue salience per country (1995-2009). Notes: Issue salience is the average number of claims per number of sampling days.

Table 2. Top three actors in politicization (1995-2009).

\begin{tabular}{lllllll}
\hline & Actor 1 & \multicolumn{5}{c}{ Actor 3 } \\
\hline AT & Gov & $(38.4)$ & Party & $(27.4)$ & CS & $(9.4)$ \\
BE & Gov & $(28.7)$ & CS & $(23.8)$ & Party & $(19.8)$ \\
CH & Gov & $(26.8)$ & Party & $(24.5)$ & CS & $(13.1)$ \\
NL & Gov & $(34.1)$ & Party & $(19.9)$ & Exp & $(9.4)$ \\
ES & Gov & $(45.0)$ & Party & $(13.6)$ & CS & $(10.0)$ \\
UK & Media & $(31.1)$ & Gov & $(22.6)$ & Party & $(10.3)$ \\
\hline
\end{tabular}

Notes: Gov: government; CS: civil society; Exp: Experts. Share of claims in parentheses. N = 6585.

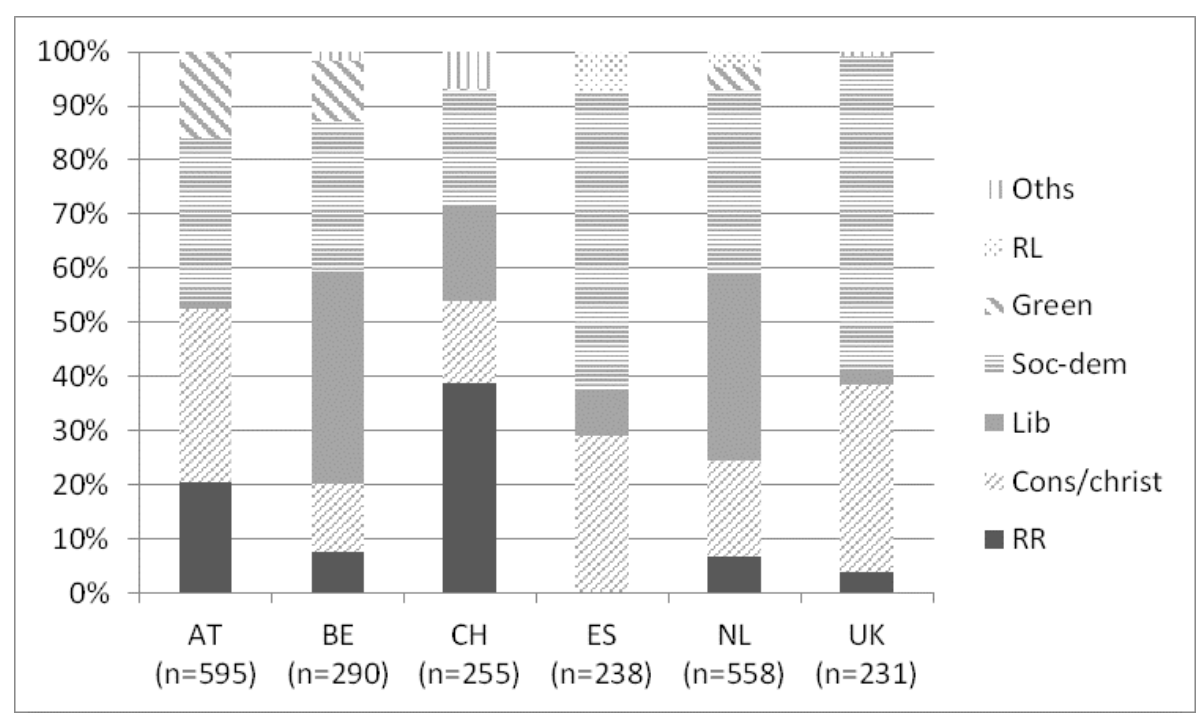

Figure 3. Share of claims per country by party family (1995-2009). 
Table 3. Average positioning according to actor type.

\begin{tabular}{llllllllll}
\hline \multicolumn{7}{c}{ All } & \multicolumn{7}{c}{ Parties } \\
\hline AT & 0.19 & $(0.68)$ & $\mathrm{n}=913$ & 0.04 & $(0.69)$ & $\mathrm{n}=511$ & -0.74 & $(0.43)$ & $\mathrm{n}=109$ \\
BE & 0.25 & $(0.69)$ & $\mathrm{n}=973$ & 0.01 & $(0.70)$ & $\mathrm{n}=249$ & -1.00 & $(0.00)$ & $\mathrm{n}=19$ \\
CH & 0.20 & $(0.65)$ & $\mathrm{n}=821$ & -0.09 & $(0.66)$ & $\mathrm{n}=220$ & -0.54 & $(0.50)$ & $\mathrm{n}=85$ \\
ES & 0.15 & $(0.67)$ & $\mathrm{n}=1019$ & 0.07 & $(0.56)$ & $\mathrm{n}=233$ & -- & - & - \\
NL & 0.14 & $(0.55)$ & $\mathrm{n}=1191$ & 0.01 & $(0.58)$ & $\mathrm{n}=498$ & -0.53 & $(0.60)$ & $\mathrm{n}=34$ \\
UK & -0.07 & $(0.84)$ & $\mathrm{n}=612$ & -0.36 & $(0.78)$ & $\mathrm{n}=154$ & -1.00 & $(0.00)$ & $\mathrm{n}=7$ \\
\hline
\end{tabular}

Note: Positioning is measured on a 5-point scale between negative (-1) and positive (1) towards immigration/migrant integration/asylum-seekers. Standard deviation in parentheses.

Even if radical right parties do not have a direct impact on the politicization of immigration as expected, they may still have an important indirect effect, for which their extreme positioning might be a first indication (see Section 2). An indirect effect is unfortunately more difficult to assess using our data. Still, our crosscountry and longitudinal design at least enables us to compare radical right presence/strength with patterns in the politicization of immigration, which will provide some indication for a potential indirect impact of radical right parties.

Our second hypothesis stated that the salience of the immigration issue should be higher in countries with politically relevant radical right parties (indicated by representation in national parliament). This is due to (a) counter-mobilization by pro-immigrant actors in response to the radical right's extreme positioning, and (b) more issue-emphasis by mainstream parties suffering electoral threats by successful radical right competitors.

Different levels of issue salience across countries can, of course, also be affected by factors related to the media system and differences in reporting styles between countries and outlets. So we have to be very cautious not to overestimate the contribution of radical right parties to differences in the various countries. Still, such comparison provides a first tentative insight into potential indirect impacts of radical right parties on the politicization of immigration.

Clustering our six countries in two groups-with and without relevant radical right parties-we would expect Austria, Belgium, the Netherlands, and Switzerland to reveal higher degrees of issue salience compared to Spain and the UK as there are no serious radical right competitors in the party system of the latter two. As reflected in the average salience measure for each country, however, this is not what we find (see Figure 2). Considering the whole 15-year-period, Spain (1.38) and the UK (1.21) outperform both Switzerland and Belgium despite the former two's absence of radical right parties in national parliament.

Turning from radical right presence to strength, we hypothesized a positive relation between radical right strength and issue salience. We explore this potential relation in two steps. First, we compare the predicted order of countries according to radical right strength against country-averages on issue salience: considering the whole time frame, we would expect Switzerland and Austria to reveal the most intense debates on immigration, reflected in the highest shares of issue salience. Both countries yield considerable-and (temporarily) increasing-radical right presence in parliament. Contrariwise, Spain and the UK should display comparatively low levels of issue salience, whereas Belgium and the Netherlands should rank in between. As shown in Figure 2, this is not what we find. The Netherlands show the highest proportion of claims (1.83) by far. However, this is not least due to the outlier in 2004, when the yearly averages strongly-and temporarilyincreased as the issue became highly salient around the time of the murder of film-maker Theo van Gogh (cf., Berkhout, Sudulich, \& van der Brug, 2015). As expected, Austria shows comparatively high levels of salience (1.4), whereas Switzerland only ranks second to last (1.18) notwithstanding the strength and continuous growth of the SVP in the Swiss party system. Spain (1.38) and the UK (1.21) outperform both Switzerland and Belgium despite the former two's absence of radical right parties in national parliament.

Second, we focus on temporal trends within countries. Over-time variation should be particularly pronounced in the Netherlands, Austria, and Switzerland: issue salience should have strongly increased in the Netherlands in 2002, it was assumed to decrease in Austria in 2003 before rising again in 2009, and it should have steadily increased in Switzerland (see Table 1). Figures 4-9 show patterns in issue salience, share of radical right claims (grey and black bars, left vertical axis) and radical right party strength (black line, right vertical axis) per country.

Austria had three peaks in issue salience-in 2001, 2007, and 2009-, showing at least some correspondence to temporal patterns in radical right strength, though not always simultaneously. Until 2007, Belgian radical right parties steadily gained strength in parliament. Issue salience, on the other hand, reflects more fluctuation-sometimes in the opposite directionthan one might expect: Issue salience decreased in 
1999 and 2003 although the radical right strengthened its presence in parliament. In Switzerland, changes in salience values correspond to increasing radical right party strength only in 2007, whereas salience decreases although the SVP's share of seats increased in 1999 and 2003; the 1998 peak in salience precedes the SVP's electoral victory in 1999, while the opposite happened in 2003/2004. The Netherlands are characterized by two peaks: The electoral success of the LPF in 2002-corresponding to a small increase in issue salience-and the salience outlier in 2004 related to the murder of film-maker van Gogh. Excluding the latter, however, there is no evidence for an increase in issue salience from 2002 onwards compared to the prior period, when radical right parties did not have any electoral success and hence no parliamentary presence. Since there are no radical right parties in either the Spanish or British parliaments, temporal patterns in issue salience cannot be related to the strength of this party family at all.

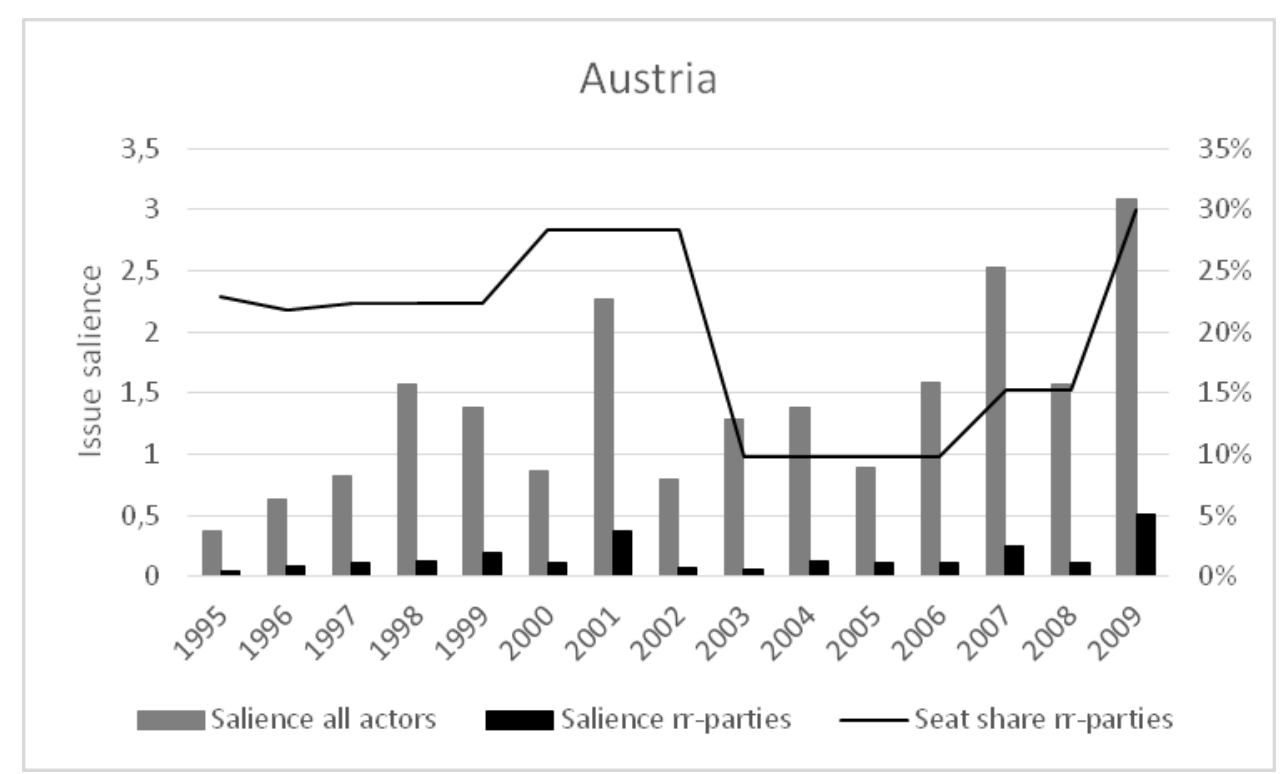

Figure 4. Austria.

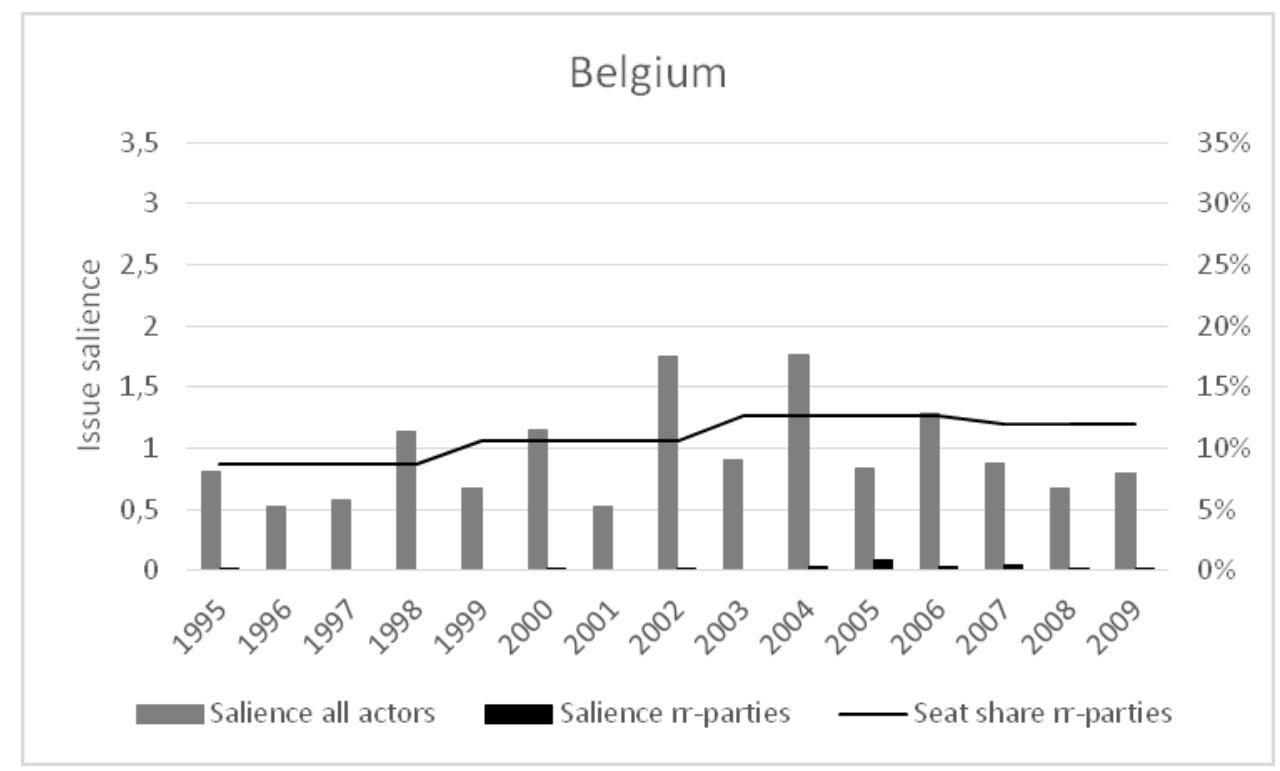

Figure 5. Belgium. 


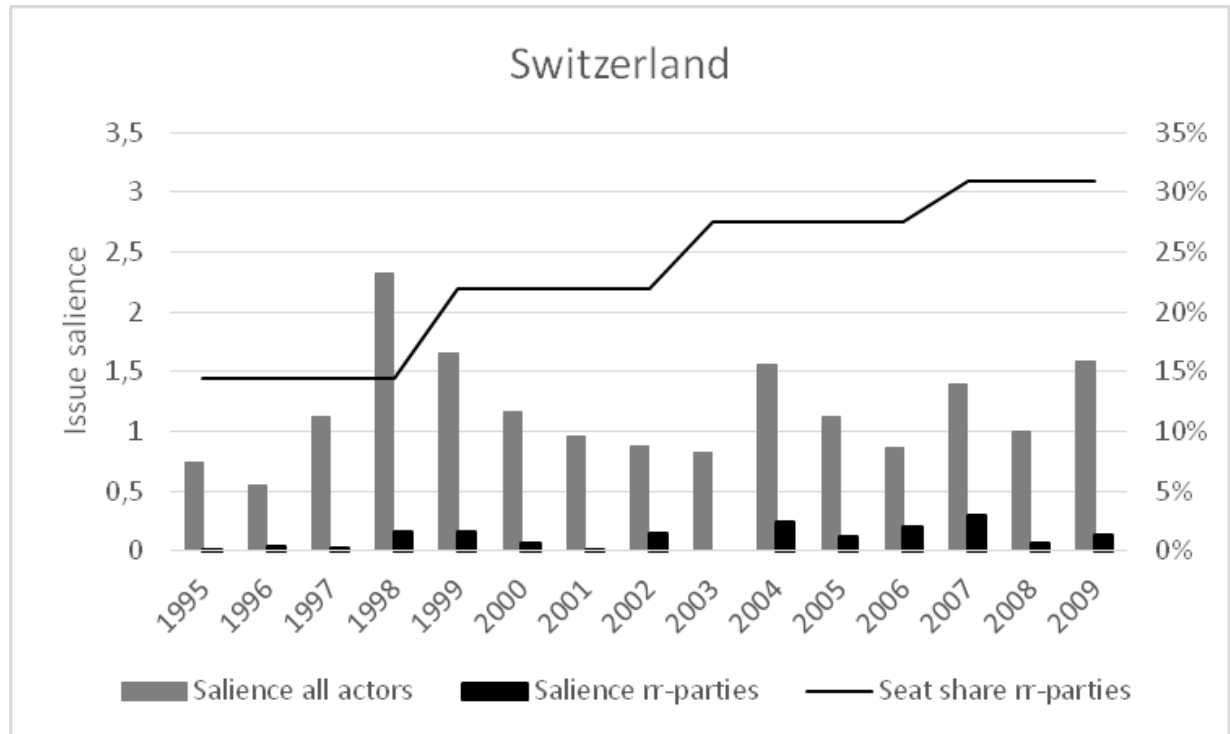

Figure 6. Switzerland.

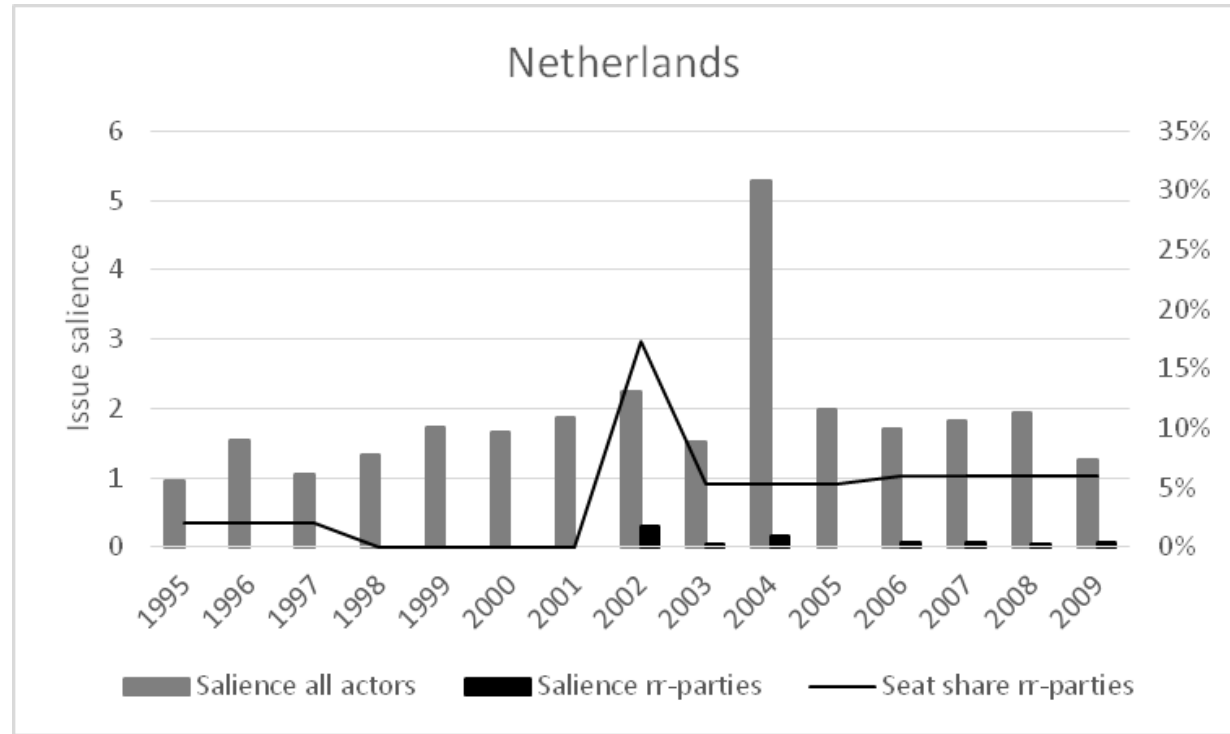

Figure 7. The Netherlands.

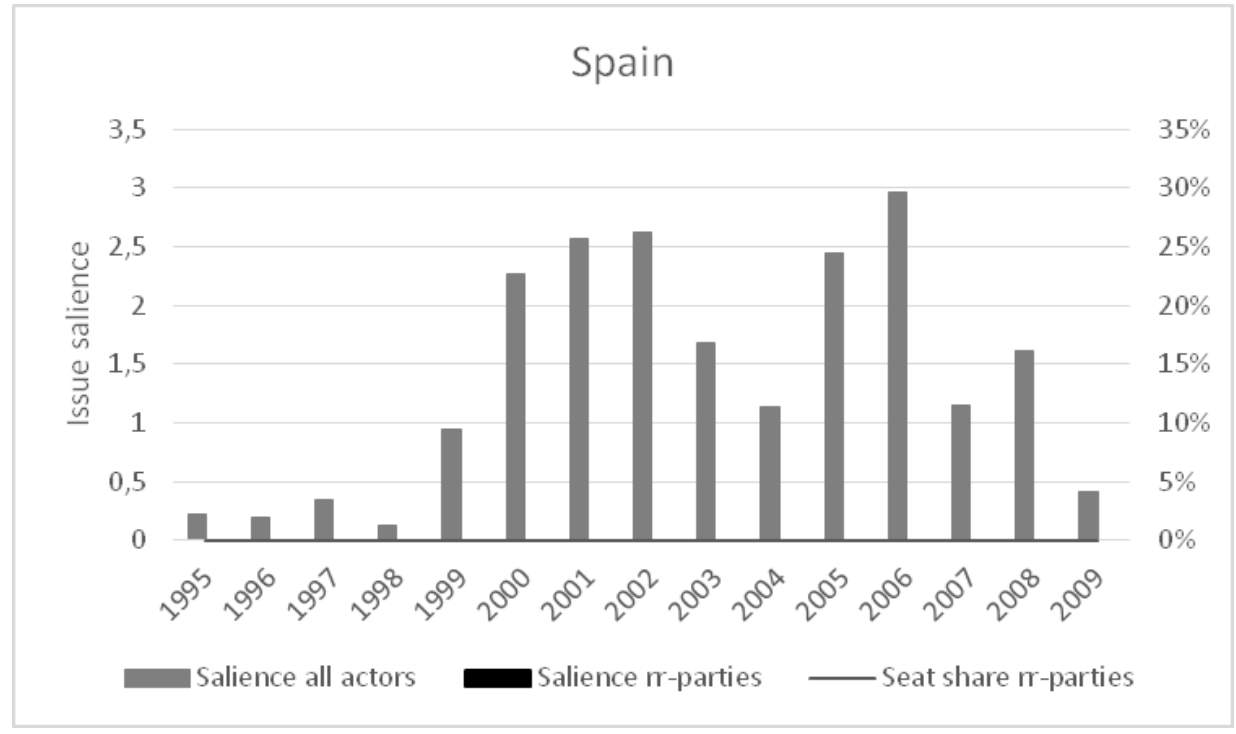

Figure 8. Spain. 


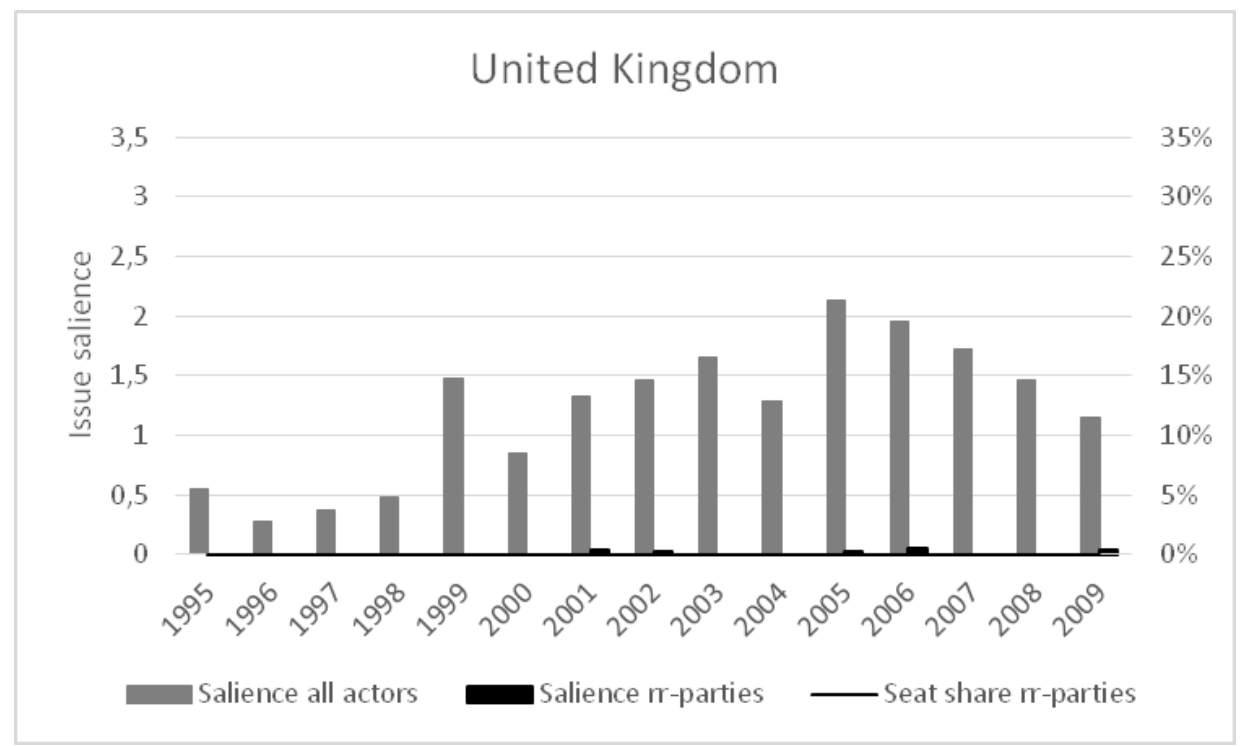

Figure 9. United Kingdom.

Figures 4-9. Issue salience and radical right (rr) party strength over time.

The longitudinal analysis within countries again reveals no systematic pattern confirming the hypothesized relation between strength of radical right parties and the salience of the immigration issue: for instance, the number of claims has not grown considerably in Switzerland despite the SVP having steadily increased its power. Likewise, the Netherlands and Spain display considerable peaks that are not related to the performance of radical parties; and the Austrian pattern does not allow for a straightforward conclusion either, as salience figures increase and decrease with no clear-cut correspondence to radical right parties' electoral or parliamentary strength.

All in all, issue salience in a given country thus seems to be unrelated to radical right party presence and strength. A comparison of Spain, the UK and Switzerland clearly reveals that neither the absence of relevant radical right parties (Spain and UK) nor their strength in the party system (Switzerland) are reflected by the degree of politicization of immigration in a given country.

In summary, our findings clearly show that radical right parties are not the dominant actors in the politicization of immigration. It is, above all, the governing actors and mainstream parties who emphasize the issue. Neither does radical right presence/strength seem to have an impact on total issue salience and temporal trends therein. This, however, does not preclude that radical right parties have an important indirect effect on their competitors' strategies. The large number of claims by governing and other party actors may indeed be a response to electoral pressure from the radical right. Bearing this in mind, the fact that Spain and the UK reveal a slightly different composition of actors in the politicization of immigration compared to the other countries calls for a more detailed analysis of the po- tential indirect radical right impact-a point to which we will return in the conclusion of this paper.

\section{Conclusion and Outlook}

As indicated in scholarly work on radical right parties in Europe, this paper was based on the assumption that this party family would play a key role in the politicization of immigration in the media. In line with the salience theory of party competition, it was assumed that radical parties - who are considered the "owners" of the immigration issue-would be most active in claimsmaking on immigration compared to other party families. We also assumed that their strong position within the party system would be reflected in the issuepoliticization of immigration in a given country: countries with a strong radical right party presence were expected to reflect higher levels of issue-politicization compared to countries lacking such presence; furthermore, the stronger the radical right, the higher the degree of issue-politicization. The reason for this is that other parties can be expected to pick up on issues of their competitors depending on the competitor's strength in the party system. We explored these hypotheses empirically using data from the SOM claims analysis in six Western European countries reflecting variation in the presence and strength of radical right parties, covering a period of 15 years (1995-2009).

In contrast to our expectations, our findings indicate that radical right parties play a subordinate role in the politicization of immigration. First, radical right parties are not the drivers of the politicization of immigration in the media. Both mainstream left and right parties reveal higher shares of claims on immigration than their radical right competitors. The exception is the 
Swiss SVP, which turns out to be the main claimant on immigration issues in Switzerland. Second, overall issue salience does not seem to be related to either radical right party presence or strength. Cross-country comparison reveals higher degrees of issue salience than expected for the UK and Spain (despite no relevant radical right parties), whereas Switzerland does not come up to our expectations. Temporal trends in issue salience do not support the hypothesis either: Peaks in issue salience do not follow a clear-cut pattern in line with radical right parties' strength (indicated by electoral success and the share of seats in parliament).

According to our data and analytical approach, radical right parties seem to be much less important in the politicization of immigration than assumed in general. This finding yields some important questions. First, why are mainstream parties so dominant in the politicization of immigration, while radical right parties are not? Second, what other reasons serve to explain trends in the politicization of immigration? While it goes beyond the scope of this paper to systematically test alternative explanations for issue-politicization of immigration, we will briefly address these questions in the remainder of this paper.

The dominant role played by mainstream parties in the politicization of immigration strongly questions the importance of party family, ideology, and issueownership as determinants of party issue-politicization, since these factors made us expect radical right parties to be much more important. Rather, it points to party strength and government participation as promising explanatory factors. The Swiss case illustrates this very well: only the SVP turns out to be the party with the highest share of claims, whereas their radical right counterparts in the other countries unexpectedly lag behind their mainstream competitors. However, the SVP is a special case with regard to various aspects. Whilst it is a right-wing anti-immigrant party, it is not a radical right party in terms of its historical origins. Furthermore, due to Switzerland's specific governing system, the SVP was constantly represented in Swiss consociational government during our period of investigation. Finally, the SVP has become the largest party in Switzerland since the 1999 elections. Therefore, the findings for the SVP may be associated to a lesser extent to party family but rather more to party size and governing authority.

As mentioned above, media coverage may not represent a balanced picture of different actors' claimsmaking efforts. Though there is no reason to believe that claims by the radical right will generally be excluded from coverage, a number of studies (e.g., Koopmans et al., 2005; Koopmans, 2007) have shown that government actors generally seem to dominate claimsmaking in the media, since their claims are viewed as either more newsworthy or reliable, or because government actors have better access to news coverage. Thus the high share of mainstream parties' claims on immigration may be related to their status as governing parties in some cases. However, we did not find systematic evidence for an increase in radical right parties' claims once these actors became part of a national government. Still, we cannot preclude with certainty that non-governing radical right parties may be underrepresented in claims-making as reported in the media. Future research should concentrate on a comparison of different data types on political parties' attempts to politicize the immigration issue, comparing e.g., issue-emphasis in press releases with media data, or parliamentary activities with party campaigning. ${ }^{19}$ This would be a fruitful way to overcome the potential bias in media data regarding an adequate representation of non-governing parties' efforts to politicize an issue. Our research design did not allow for such an approach.

Even though radical right party strength did not emerge as a good predictor for the salience of issuepoliticization on immigration, mainstream parties' large share of claims could still be a reaction to electoral pressure from the radical right. Assessing this potential indirect impact of the radical right in more detail, however, requires a different research strategy and goes beyond the scope of this paper.

Another interesting question is whether there is any reason to believe that radical right parties actually make fewer claims on an issue than their competitors. Why would that be the case? Immigration may primarily be addressed by them focusing on a problem definition ("too many foreigners") rather than a political solution ("we demand $x$ or $y$ in order to overcome the problem"). This would be in line with their simplistic policy program and often populist strategies of mobilization. In that case, claims-making would be a bad indicator for issuepoliticization in respect of this particular actor. However, the operational definition of claims applied in our research was very broad and did not only cover political solutions, which is why we are quite sure that radical right parties had the same chances as other parties to have their messages conveyed. Still, future studies may explicitly address this matter, e.g., systematically distinguishing between problem definition and claims for political solutions articulated by political parties.

Turning our focus to alternative explanations for the overall degree of issue-politicization on immigration at the country level, and temporal trends therein, two approaches are repeatedly discussed in the literature: first, objective conditions concerning immigration to a country, and, second, the role that events play. Objective conditions, such as immigration numbers and the composition of immigrant populations, were studied in detail within the larger framework of the SOM project. While the findings showed that the issue was not politicized in

${ }^{19}$ See e.g., Vliegenhart \& Roggenband (2007), who compare the salience and framing of immigration/integration in the Dutch press and parliament. 
the absence of noticeable immigration numbers, temporal trends in the salience of the issue were unrelated to immigration flows (cf., van der Brug et al., 2015; see also Vliegenthart, \& Boomgaarden, 2007). It is more difficult with regard to the role events play, which seems to be an important aspect when it comes to explaining certain peaks in politicization (Vliegenthart, \& Boomgaarden, 2007). Still, further research is needed if we seek to understand why certain events turn out as triggers for politicization while others don't.

Recent contributions to the study of radical or extreme right anti-immigrant parties indicate that the latter's impact on politics may be overestimated (cf., Akkerman, 2012; Alonso \& Fonseca, 2012). ${ }^{20}$ Our findings support this assessment. Despite some serious limitations discussed above, our study clearly revealed that anti-immigrant radical right parties were sparsely represented in claims-making on immigration in the media in the period 1995-2009; an exception is the Swiss SVP. Their unique contribution to the politicization of immigration rather seems to be their extreme positioning, which may also function as a driver of other parties' attempts to address the issue. In conclusion, while scholarly literature on the emergence and success of radical right parties is extensive, more comparative research should be devoted to their precise role in influencing the political and, in particular, the mass media agenda. We have not got any satisfactory answers to this question as yet.

\section{Acknowledgements}

We would like to thank Astrid Mattes for her contribution to a previous version of the paper.

\section{Conflict of Interests}

The authors declare no conflict of interests.

\section{References}

Akkerman, T. (2012). Comparing radical right parties in government: Immigration policies in nine countries (1996-2010). West European Politics, 35(3), 511-529.

Alonso, S., \& Fonseca, S. C. (2012). Immigration, left and right. Party Politics, 18(6), 865-884.

Bale, T., Green-Pedersen, C., Krouwel, A., Luther, K. R., \& Sitter, N. (2010). If you can't beat them, join them? Explaining social democratic responses to the challenge from the populist radical right in Western Europe. Political Studies, 58(3), 410-426.

Berkhout, J., \& Sudulich, L. (2011). Codebook for political claims analysis. Website SOM project. Retrieved from http://www.som-project.eu

20 See e.g., Dunn \& Singh (2011) on the limited impact on public tolerance towards minorities.
Berkhout, J., Sudulich, L., \& van der Brug, W. (2015). The politicisation of immigration in the Netherlands. In W. van der Brug, G. D'Amato, J. Berkhout, \& D. Ruedin (Eds.), The politicisation of immigration: A comparative study of seven countries (19952009). Abingdon: Routledge.

Budge, I. (1982). Electoral volatility: Issue effects and basic change in 23 post-war democracies. Electoral Studies, 1(2), 147-168.

Budge, I. \& Farlie, D. J. (1983). Party competitionSelective emphasis or direct confrontation? An alternative view with data. In H. Daalder \& P. Mair (Eds.), Western European party systems (pp. 267305). London: Sage.

Budge, I., Klingemann, H.-D., Volkens, A., Bara, J., \& Tannenbaum, E. (2001). Mapping policy preferences: Estimates for parties, electors, and governments, 1945-1998. Oxford: Oxford University Press.

Carmines, E. G., \& Stimson, J. A. (1986). On the structure and sequence of issue evolution. American Political Science Review, 80(3), 901-920.

Carmines, E. G., \& Stimson, J. A. (1989). Issue evolution. Race and the transformation of American politics. Princeton: Princeton University Press.

Carter, E. (2005). The extreme right in Western Europe. Success or failure? Manchester: Manchester University Press.

Cinalli, M., \& Giugni, M. (2007). Codebook: Discursive interventions in the local polity and their impact on the political integration of immigrants. Website LOCALMULTIDEM project. Retrieved from http://www. um.es/localmultidem/projectoutputs.php?type $=\mathrm{R}$

De Wilde, P. (2011). No polity for old politics? A framework for analyzing the politicization of European integration. Journal of European Integration, 33(5), 559-575.

Downs, W. M. (2001). Pariahs in their midst: Belgian and Norwegian parties react to extremist threats. West European Politics, 24(3), 23-42.

Dunn, K. P., \& Singh, S. P. (2011). The surprising nonimpact of radical right-wing Populist Party representation on public tolerance of minorities. Journal of Elections, Public Opinion \& Parties, 21(3), 313-331.

Eatwell, R. (2000). The rebirth of the "extreme right" in Western Europe? Parliamentary Affairs, 53(3), 407425.

Givens, T. (2005). Voting radical right in Western Europe. New York: Cambridge University Press.

Givens, T., \& Luedtke, A. (2005). European immigration policies in comparative perspective: Issue salience, partisanship and immigrant rights. Comparative European Politics, 3(1), 1-22.

Green-Pedersen, C. (2012). A giant fast asleep? Party incentives and the politicisation of European integration. Political Studies, 60(1), 115-130.

Gruber, O. (2014). The electoral politicization of immigration and ethnic relations in Austrian general 
elections, 1971-2013. Berlin: LIT Verlag.

Hagelund, A. (2003). A matter of decency? The Progress Party in Norwegian immigration politics. Journal of Ethnic and Migration Studies, 29(1), 47-65.

Halikiopoulou, D., \& Vasilopoulou, S. (2010). Towards a "civic" narrative: British national identity and the transformation of the British National Party. Political Quarterly, 81(4), 583-592.

Heinisch, R. (2003). Success in opposition-Failure in government: Exploring the performance of the Austrian Freedom Party and other European right-wing populist parties in public office. West European Politics, 26(3), 91-130.

Helbling, M. (2014). Framing immigration in Western Europe. Journal of Ethnic and Migration Studies, 40(1), 21-41.

Hooghe, L., \& Marks, G. (2009). A postfunctionalist theory of European integration: From permissive consensus to constraining dissensus. British Journal of Political Science, 39(1), 1-23.

Ivarsflaten, E. (2008). What unites right-wing populists in Western Europe? Re-examining grievance mobilization models in seven successful cases. Comparative Political Studies, 41(1), 3-23.

Kitschelt, H. P. (1995). The radical right in Western Europe. A comparative analysis. Ann Arbor: University of Michigan Press.

Koopmans, R. (2002). Codebook for the analysis of political mobilisation and communication in European public spheres. Website EUROPUB project. Retrieved from http://europub.wzb.eu/Data/Codeboo ks\%20questionnaires/D2-1-claims-codebook.pdf

Koopmans, R. (2007). Who inhabits the European public sphere? Winners and losers, supporters and opponents in Europeanised political debates. European Journal of Political Research, 46(2), 183-210.

Koopmans, R., \& Statham, P. (2000). Political claimsmaking against racism and discrimination in Britain and Germany. In J. Ter Wal \& M. Verkuyten (Eds.), Comparative perspectives on racism (pp. 139-170). Aldershot: Ashgate.

Koopmans, R., Statham, P., Giugni, M., \& Passy, F. (2005). Contested citizenship. Immigration and cultural diversity in Europe. Minneapolis: University of Minnesota Press.

Krzyzanowski, M. (2013). From anti-immigration and nationalist revisionism to islamophobia: Continuities and shifts in recent discourses and patterns of political communication of the Freedom Party of Austria (FPÖ). In R. Wodak, M. KhosraviNik, \& B. Mral (Eds.), Right-wing populism in Europe. Politics and discourse (pp. 135-148). London: Bloomsbury.

Lipset, S. M., \& Rokkan, S. (1967). Cleavage structures, party systems, and voter alignment: An introduction. In S. M. Lipset \& S. Rokkan (Eds.), Party systems and voter alignments: Cross-national perspectives (pp. 1-64). New York/London: Free Press.
Meguid, B. M. (2005). Competition between unequals: The role of mainstream party strategy in niche party success. American Political Science Review, 99(3), 347-359.

Minkenberg, M. (2000). The renewal of the radical right: Between modernity and anti-modernity. Government and Opposition, 35(2), 170-188.

Minkenberg, M. (2001). The radical right in public office: Agenda-setting and policy effects. West European Politics, 24(4), 1-21.

Minkenberg, M. (2002). The new radical right in the political process: Interaction effects in France and Germany. In M. A. Schain, A. Zolberg \& P. Hossay (Eds.), Shadows over Europe: The development and impact of the extreme right in Western Europe (pp. 245-268). New York: Palgrave Macmillan.

Minkenberg, M. (2008). The radical right in Europe: An overview. Gütersloh: Verlag Bertelsmann Stiftung.

Mudde, C. (1996). The war of words: Defining the extreme Right Party family. West European Politics, 19(2), 225-248.

Mudde, C. (1999). The single-issue party thesis: Extreme right parties and the immigration issue. West European Politics, 22(3), 182-197.

Mudde, C. (2013). Three decades of populist radical right parties in Western Europe: So what? European Journal of Political Research, 52(1), 1-19.

Norris, P. (2005). Radical right. Voters and parties in the electoral market. New York: Cambridge University Press.

Page, B. I. (1996). The mass media as political actors. PS: Political Science and Politics, 29(1), 20-24.

Ros, V., \& Morales, L. (2012). Political opportunity structure: Country report "Spain". Unpublished manuscript.

Rosenberger, S., \& Hadj-Abdou, L. (2013). Islam at issue: Anti-islamic mobilisation of the extreme right in Austria. In A. Mammone, E. Godin, \& B. Jenkins (Eds.), Varietes of right-wing extremism in Europe (pp. 149-163). London: Routledge.

Rydgren, J. (2005). Is extreme right-wing populism contagious? Explaining the emergence of a new party family. European Journal of Political Research, 44(3), 413-437.

Rydgren, J. (2007). The sociology of the radical right. Annual Review of Sociology, 33, 241-262.

Schain, M. (2006). The extreme-right and immigration policy-making: Measuring direct and indirect effects. West European Politics, 29(2), 270-289.

Sartori, G. (1976). Parties and party systems: A framework for analysis. Cambridge: Cambridge University Press.

Schattschneider, E. E. (1975). The semisovereign people. A realist's view of democracy in America. Hindsdale: Dryden.

Semyonov, M., Raijman, R., \& Gorodzeisky, A. (2006). The rise of anti-foreigner sentiment in European so- 
cieties, 1988-2000. American Sociological Review, 71(3), 426-449.

Skenderovic, D., \& D’Amato, G. (2008). Mit dem Fremden politisieren. Rechtspopulismus und Migrationspolitik in der Schweiz. Zürich: Chronos Verlag.

SORA. (2006). Analysen zur Nationalratswahl 2006. Website Institute for Social Research and Analysis (SORA). Retrieved from http://www.sora.at/file admin/downloads/wahlen/2006_nrw_wahltagsbe fragung_presseunterlage.pdf

Sprague-Jones, J. (2011). Extreme right-wing vote and support for multiculturalism in Europe. Ethnic and Racial Studies, 34(4), 535-555.

Statham, P., \& Geddes, A. (2006). Elites and organized publics: Who drives British immigration politics and in which direction? West European Politics, 29(2), 248-269.

Statham, P., \& Koopmans, R. (2009). Political party contestation over Europe in the mass media: Who criticizes Europe, how, and why? European Political Science Review, 1(3), 435-463.

Steenbergen, M. R. \& Scott, D. J. (2004). Contesting Europe? The salience of European integration as a party issue. In G. Marks \& M.R. Steenbergen (Eds.), European integration and political conflict (pp. 165192). Cambridge: Cambridge University Press.

Taggart, P. (1995). New populist parties in Western Europe. West European Politics, 18(1), 34-51.

Van der Brug, W., \& Fennema, M. (2007). Causes of voting for the radical right. International Journal of Public Opinion Research, 19(4), 474-487.

Van der Brug, W., Fennema, M., \& Tillie, J.N. (2005). Why some anti-immigrant parties fail and others succeed: A two-step model of aggregate electoral support. Comparative Political Studies, 38(5), 537573.

Van der Brug, W., D’Amato, G., Berkhout, J., \& Ruedin, D. (Eds.). 2015. The politicisation of immigration: $A$ comparative study of seven countries (1995-2009). Abingdon: Routledge. Forthcoming.

Van Heerden, S., de Lange, S. L., van der Brug, W., \& Fennema, M. (2014). The immigration and integration debate in the Netherlands: Discursive and programmatic reactions to the rise of anti-immigration parties. Journal of Ethnic and Migration Studies, 40(1), 119-136.

Van Spanje, J. (2010). Contagious parties. Antiimmigration parties and their impact on other parties' immigration stances in contemporary Western Europe. Party Politics, 16(5), 563-586.

Van Spanje, J. H., \& van der Brug, W. (2007). The party as pariah: the exclusion of anti-immigration parties and its effect on their ideological positions. West European Politics, 30(5), 1022-1040.

Vliegenthart, R., \& Roggenband, C. (2007). Framing immigration and integration: Relationships between press and Parliament in the Netherlands. International Communication Gazette, 69(3), 295-319.

Vliegenthart, R., \& Boomgaarden, H. G. (2007). Realworld indicators and the coverage of immigration and the integration of minorities in Dutch newspapers. European Journal of Communication, 22(3), 293-314.

Westin, C. (2003). Racism and the political right: European perspectives. In P. H. Merkl \& L. Weinberg (Eds.), Right-wing extremism in the twenty-first century (pp. 97-125). London: Frank Cass Publishers.

Wilp, M. (2012). Populismus in den Niederlanden-die Freiheitspartei von Geert Wilders. In Sir Peter Ustinov Institut (Ed.), Populismus. Herausforderung oder Gefahr für die Demokratie? (pp. 75-90). Wien: New Academic Press.

Wodak, R., \& Köhler, K. (2010). Wer oder was ist "fremd"? Diskurshistorische Analyse fremdenfeindlicher Rhetorik in Österreich. SWS-Rundschau, 50(1), 35-55.

\section{About the Authors}

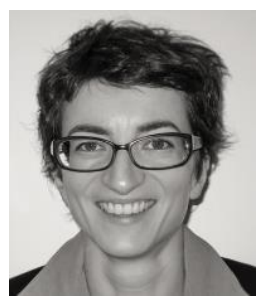

\section{Dr. Sarah Meyer}

Sarah Meyer holds a PhD in Political Science from the University of Vienna. As part of the research group INEX "The Politics of Inclusion \& Exclusion" she has worked in the FP7 project SOM "Support and Opposition to Migration" and "Taking Sides: Protest Against the Deportation of Asylum Seekers", funded by the Austrian Science Foundation (FWF). Her research focuses on processes of politicization, in particular European integration, migration \& asylum.

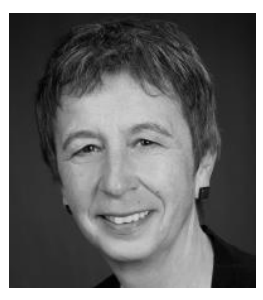

\section{Dr. Sieglinde Rosenberger}

Sieglinde Rosenberger is Professor at the Department of Political Science at the University of Vienna. Her main research interests are democracy and differences, governing diversity (including religion), political participation, and gender studies. She is head of the research group INEX "The Politics of Inclusion \& Exclusion", University of Vienna (http://inex.univie.ac.at). Publications include: Rosenberger, S., \& Winkler, J. (2014). Com/passionate protests: Fighting the deportation of asylum seekers. Mobilization: An International Quarterly, 19(2), 165-184. 